\title{
ARTIKELEN
}

\author{
THEMA-ARTIKELEN
}

\section{De pandemie als spiegel}

\section{Bestuurskundig leren van de aanpak van de COVID-19-crisis}

Myrthe van Delden, Wiljan Hendrikx, Shelena Keulemans \& Martijn van der Steen*

\section{Inleiding}

Begin 2020 voorzagen weinig mensen de crisis die voor de deur stond. Lange tijd leek de coronacrisis een 'Chinese crisis', zelfs nog toen de besmettingen ook in Italië en Oostenrijk plaatsvonden. Met wat is gaan heten 'het briefje van Bruins', werd ook in Nederland de coronacrisis een feit. Wanneer de uitzending van de speciale NOS-avond over het coronavirus start op donderdagavond 27 februari 2020, is de eerste besmetting in Nederland nog niet bevestigd. Tijdens de uitzending krijgt minister Bruins van Medische Zorg een briefje in handen gedrukt, waarna hij tijdens de uitzending de eerste besmetting in Nederland bevestigt. Ondanks dat sommigen dachten dat deze gebeurtenis in scène was gezet, geven betrokken ambtenaren aan dat dit een spontaan, echt moment was; een kenmerkend moment voor de start van de crisis voor het brede, Nederlandse publiek, waarin openbaar bestuur en samenleving steeds weer leken te worden ingehaald door de werkelijkheid.

'Met 50 procent van de kennis moeten we 100 procent van de besluiten nemen'. ${ }^{1}$ Met deze woorden typeerde minister-president Rutte de enorme opgave waar politiek en bestuur voor kwamen te staan, toen in de eerste maanden van 2020 de COVID19-crisis in alle hevigheid losbarstte. Uiteraard kenmerken deze condities van begrensde rationaliteit (vergelijk Simon, 1955) het openbaar bestuur in zekere zin altijd en is het juist de kracht van het openbaar bestuur dat, ondanks beperkte kennis, voor de maatschappij beslissingen kunnen worden gewogen en genomen.

Toch waren - en zijn - de schaal en aard van deze crisis voor het moderne openbaar bestuur ongekend. Daar waar bestaande wet- en regelgeving, evenals formele en informele instituties, al vrijwel direct tekortschoten, werd het politieke, bestuurlij-

* T.A.M. van Delden, MSc is onderzoeker en opleidingsmanager van de Nederlandse School voor Openbaar Bestuur (NSOB). Dr. P.M.A. Hendrikx is onderzoeker en opleidingsmanager van de NSOB. Dr. S.A.C. Keulemans is universitair docent Bestuurskunde aan de Radboud Universiteit. Prof. dr. M.A. van der Steen is bijzonder hoogleraar bij de Erasmus Universiteit Rotterdam, en is tevens co-decaan en adjunct-directeur van de NSOB en directeur van de Denktank.

1 Rutte, M. (2020, 12 maart). We hebben iedereen nodig, 17 miljoen mensen. Persconferentie: https:// nos.nl/video/2326873-rutte-we-hebben-iedereen-nodig-17-miljoen-mensen. 
ke, ambtelijke en maatschappelijke vermogen tot veerkracht tot het uiterste gedreven. Razendsnel moesten creatieve, innovatieve en passende oplossingen worden bedacht voor opkomende problemen, soms met weinig tijd voor de reguliere besluitvormingsprocessen die cruciaal zijn voor het goed functioneren van de democratische rechtsstaat. En dat alles in het volle besef dat in de haast onvermijdelijk ook ruimte ontstond voor fouten of onbedoelde neveneffecten.

Tijdens een crisis, en daar is deze crisis geen uitzondering op, is een veelgehoorde kreet 'never waste a good crisis'. Deze grootste crisis van en voor het openbaar bestuur sinds de Tweede Wereldoorlog confronteert het openbaar bestuur met tal van uitdagingen, maar creëert eveneens kansen om als bestuurskundige discipline te leren en om te reflecteren op bestaande ideeën en aannames binnen het openbaar bestuur. In dat kader staat in dit themanummer van Bestuurskunde het leren van de coronacrisis centraal, zowel voor de praktijk, maar óók voor de bestuurskunde zelf. Nu het stof van de crisis begint neer te dwarrelen, kunnen vragen worden gesteld als: Welke crisisstrategieën zijn effectief gebleken in de praktijk, en welke niet? Heeft de coronacrisis bijgedragen aan innovaties binnen het openbaar bestuur? Welke lessen vanuit de literatuur, zoals de crisisliteratuur, zijn juist of fout gebleken? Wat kan het openbaar bestuur van de aanpak van de coronacrisis leren, om eventueel toekomstige crises adequaat aan te pakken?

Dit themanummer adresseert deze vragen door de bestuurlijke aanpak van de COVID-19-crisis vanuit bestuurskundig perspectief te beschouwen. De verschillende bijdragen beogen het openbaar bestuur een kritische spiegel voor te houden en te reflecteren op de (on)mogelijkheden waarmee de politieke en bestuurlijke besluitvorming zich geconfronteerd zag en ziet. De bijdragen variëren daartoe door elk in te gaan op een ander aspect van de crisisaanpak door het openbaar bestuur: van empirisch georiënteerde analyses van de daadwerkelijke aanpak, tot meer fundamentele beschouwingen over de rol van de overheid; van het verkrijgen van democratische legitimiteit aan de voorkant, tot verantwoording en evaluatie tijdens en achteraf.

\section{Bijdragen aan dit themanummer}

De aanpak van de COVID-19-crisis kent veel facetten en kan vanuit verschillende perspectieven worden beschouwd. In dit themanummer beschouwen we de aanpak van deze crisis op internationaal-vergelijkend, nationaal en sectoraal niveau. Daarnaast wordt de impact van de COVID-19-crisis op het digitale werken en de relaties overheid-burger en beleidsvorming-wetenschap verkend.

In de eerste, en enige Engelstalige, bijdrage aan dit themanummer brengt Michael Howlett de opbrengsten van een grote, internationaal vergelijkende studie bij elkaar. Hij identificeert een zestal strategieën die nationale overheden hebben gehanteerd om de pandemie het hoofd te bieden door empirisch te kijken naar de verschillende beleidsinstrumenten die zij hebben ingezet. Welke strategie een overheid heeft gehanteerd, blijkt afhankelijk van verschillen in capaciteit en slagkracht van overheden, niveau van paraatheid en leiderschap. De auteur laat zien 
dat wanneer eenmaal voor een crisisstrategie is gekozen, het lastig is gebleken hier in een latere fase van de pandemie alsnog vanaf te wijken.

De tweede bijdrage verdiept zich verder in internationale verschillen in de aanpak van de COVID-19-crisis. Marleen Bekker en Ivo ten Have onderzoeken in een selectie van 48 Aziatische en Europese landen de aanpak van de COVID-19-crisis van verschillende nationale overheden. Zij vergelijken hun sturing van pandemische paraatheid, overeenkomsten en verschillen in pandemische plannen, en overeenkomsten, verschillen en verschuivingen in hun COVID-19-beleidsrespons. Zij verdiepen deze vergelijking door in te zoomen op een beperkte selectie van landen met respectievelijk zonder grootschalige blootstelling aan SARS in 2003. De auteurs concluderen dat pandemische plannen weinig voorspellende waarde hebben voor de gouvernementele beleidsrespons op COVID-19, omdat deze plannen voornamelijk gingen over risicosignalering en ziektebestrijding. Juist niet-medische gedragsmaatregelen bleken cruciaal, terwijl deze in de plannen nagenoeg ontbraken. De landen die eerder blootgesteld waren aan SARS, waren vervolgens beter voorbereid op de nieuwe pandemie en hadden geen verschuivingen in bestuur of wetgeving nodig, maar hadden een adequate structuur en capaciteit onderhouden en waren daarmee paraat.

Naast de nationale overheid spelen de vitale sectoren een cruciale rol in de aanpak van de COVID-19-crisis. De derde en vierde bijdrage richten zich op twee van die sectoren: de zorg en de veiligheidsregio's. In hun bijdrage analyseren Jelmer Schalk, Eduard Schmidt, Suzan van der Pas, Sietse Wieringa, Sandra Groeneveld en Jet Bussemaker het tweebenig besturen dat wordt gevraagd van zorgbestuurders in crisismanagement. In hun analyse laten de auteurs zien dat een multi-actor en multi-level zorgnetwerk zowel bijdraagt aan innovatie als aan consolidatie, maar dat het per fase van de crisis verschilt op welke manier dit gebeurt.

In de bijdrage 'Corona als stresstest voor het binnenlands bestuur' stellen Caspar van den Berg, Geerten Boogaard, Sofie Dreef en Gert Jan Geertjes dat de meerwaarde van de crisisaanpak door de veiligheidsregio niet zozeer lag in de daadwerkelijke regionale differentiatie in de coronamaatregelen, als wel in de regionale inbedding van deze maatregelen. Aan de hand van berichten in (lokale) media over de corona-aanpak, vergelijkend onderzoek naar de noodverordeningen in de 25 veiligheidsregio's en interviews met vrijwel alle raadsvoorzitters en andere betrokkenen onderzochten de auteurs differentiatie tussen en regionale inbedding van de maatregelen en uitvoering ervan in de veiligheidsregio's.

De vijfde bijdrage biedt een microperspectief op de coronacrisis. De coronacrisis veranderde de manieren waarop ambtenaren, en met hen veel werknemers, hun werk kunnen doen. De meest ingrijpende verandering: het digitale werken. Klaartje Peters, Geerten Boogaard, Bibi van de Berg en Lianne van Kalken tekenen in hun bijdrage lessen op van digitaal vergaderen door gemeenteraden in coronatijd. Bij de invoering van de 'Tijdelijke wet digitale beraadslaging en besluitvorming' is een commissie ingesteld die de invoering en het gebruik van de wet moest gaan monitoren en evalueren. Zorgen bij de invoering van deze wet waren er vooral over de techniek en beveiliging, de rechtmatigheid en de politiek-bestuurlijke effecten van 
het digitaal vergaderen. De auteurs laten zien dat de ervaringen van gemeenteraden met digitaal vergaderen hebben aangetoond dat digitaal vergaderen voor hen in een behoefte voorziet, en niet alleen in crisissituaties.

We sluiten dit themanummer af met twee beschouwingen over wat de COVID-19crisis ons leert over de relatie overheid-burger en de relatie tussen besluitvorming en wetenschap. In de zesde bijdrage reflecteren Henk den Uijl en Paul Frissen op de vraag welke typen macht de overheid toepast in het coronabeleid, hoe deze toepassing zich verhoudt tot de vrijheid van de burger, en hoe we vrijheid tegen deze achtergrond kunnen begrijpen. Ze maken daarin onderscheid tussen positieve en negatieve vrijheid. De auteurs stellen dat de bestuurlijke COVID-19-aanpak laat zien dat er een andere, meer democratische grondhouding van ons openbaar bestuur nodig is; één waarin de staat meer zelfbewustzijn ontwikkelt ten aanzien van de soorten macht die hij uitoefent, en rekenschap geeft aan het belang van burgerlijke vrijheid.

In de laatste bijdrage beschouwen Hans de Bruijn en Martijn van der Steen vanuit een bestuurskundig perspectief de manier waarop de relatie tussen wetenschappelijke kennis en besluitvorming tijdens de eerste fase van de COVID-19-crisis invulling kreeg. De auteurs reflecteren kritisch op de oorzaken van de grilligheid van het kenniskompas voor corona-besluiten. Ze plaatsen vervolgens die discussie in een breder debat over de rol van wetenschappelijke kennis in besluitvorming. In het artikel wordt een drietal elementen uit het publieke debat over de relatie tussen wetenschap en beleid naar voren gehaald: de scheiding tussen wetenschap en besluitvorming, de noodzaak van multidisciplinair adviseren en de rol van sociale wetenschappers in het debat over COVID-19.

\section{Een blik op de toekomst}

Tezamen geven de zeven bijdragen inzicht in de complexiteit van de aanpak van de COVID-19-crisis. De uitdagingen waarvoor een crisis van deze schaal het openbaar bestuur stelt, vragen om ingrijpende maatregelen en keuzes die worden gekenmerkt door brede onzekerheidsmarges. Meer dan reflectie achteraf veronderstelt het niet verspillen van een goede crisis een blik op de toekomst. De gevolgen van de coronacrisis zullen nog lang daarna voelbaar zijn. Hoe groot de impact van de crisis op bijvoorbeeld de zorg, het onderwijs of de economie zal zijn, zal de toekomst uitwijzen. Ook het effect van de COVID-19-crisis op de bestuurlijke aandacht voor en aanpak van andere, meer sluipende crises - zoals de klimaatcrisis - moet nog blijken.

'Never waste a good crisis' impliceert dat lessen van de aanpak van de COVID-19-crisis worden ingezet voor innovaties en veranderingen ter versterking van het openbaar bestuur. Hoe het openbaar bestuur op verstandige en verantwoorde wijze kan omgaan met de nasleep van de COVID-19-crisis, en de aandacht en daadkracht voor de sluipende crises die onze toekomst kunnen vormen kan waarborgen, staat daarom centraal in het volgende themanummer van Bestuurskunde. 
De pandemie als spiegel

\section{Literatuur}

Simon, H. A. (1955). A behavioral model of rational choice. Quarterly Journal of Economics, 69(1), 99-118. 